\title{
Influence of Freeboard on Ship Stability in Rough Weather: a Probabilistic Analysis
}

Igor Bačkalov

Assistant Professor University of Belgrade Faculty of Mechanical Engineering Department of Naval Architecture

\section{Stefan Rudaković}

Ph.D. Student

University of Belgrade

Faculty of Mechanical Engineering Department of Naval Architecture
Freeboard assignment for seagoing vessels is carried out according to the deterministic provisions of the International Convention on Load Lines. In present investigation, however, an attempt is made to evaluate the influence of freeboard on the dynamic stability of ships in storms using a probabilistic approach. The probability of a stability failure of a small multipurpose cargo ship exposed to irregular beam waves and stochastic beam wind is estimated in a series of numerical experiments, whereby the freeboard of the exafmined vessel is systematically varied. The effect of freeboard is quantified in terms of a range of metacentric heights ensuring sufficient stability from the probabilistic point of view. The paper presents a step towards a procedure that could enable a better balance of safety and cost-efficiency in the ship design framework.

Keywords: Ship stability, Ship freeboard, Probabilistic analysis, Stochastic wind, Nonlinear roll.

\section{INTRODUCTION}

Freeboard is an essential element of ship safety. The modern rules for freeboard assignment applicable to seagoing ships involved in international trade were first established by the International Convention on Load Lines (ICLL) in 1930. The next ICLL was adopted by the International Maritime Organization (IMO) in 1966 and subsequently amended several times, most notably by the 1988 Protocol and the 2003 amendments.

By increasing the residuary stability and the reserve buoyancy, and by decreasing the shipping of green water, a higher freeboard has a considerable positive effect on ship safety. On the other hand, the higher freeboard increases the volume of the enclosed spaces, i.e. the gross tonnage (GT) of the ship, and generally increases the steel weight as well. Consequently, both the operational and the production costs are increased. The adopted freeboard height obviously has to be a compromise between the safety and the economy of the ship production and operation, whereby all principal dimensions should be carefully considered, as noted in [1]. An inadequate compromise, however, may lead to decreased stability, as shown in papers [2] and [3].

The goal of the present paper is to investigate an alternative approach to the freeboard assessment, based on a probabilistic analysis of ship safety in realistic weather conditions. In recent years, the probabilistic analysis of intact stability emerged as a promising alternative to the traditional methods employed in the Weather Criterion. The approach used in the present study is based on the works of Francescutto \& Bulian [4] and Vassalos et al. [5] and it was utilized in a series

Received: January 2015, Accepted: May 2015

Correspondence to: Dr. Igor Bačkalov

Faculty of Mechanical Engineering,

Kraljice Marije 16, 11120 Belgrade 35, Serbia

E-mail: ibackalov@mas.bg.ac.rs

doi:10.5937/fmet1701045B

(c) Faculty of Mechanical Engineering, Belgrade. All rights reserved of papers addressing the stability of both seagoing and inland vessels, see for instance papers [6] $\div$ [9].

In the present investigation, the probability of a stability failure of the sample ship in the beam storm (beam irregular waves and gusting beam wind) is estimated in a series of numerical experiments whereby the freeboard of the vessel is systematically varied. An effort is made to quantify the influence of the freeboard on dynamic ship stability. A classic ship safety concept is, therefore, being re-examined by modern approach.

\section{PROBABILISTIC APPROACH TO SHIP STABILITY}

The probabilistic approach to ship safety implies the evaluation of the probability of a critical event in given circumstances (i.e. in a scenario) during certain period (i.e. exposure time). In ship stability, the critical event represents a partial or total stability failure (heeling to a large angle of roll, exceeding the acceptable level of accelerations or capsizing). A potentially dangerous combination of operational aspects (ship speed, heading, loading condition) and environmental conditions (wind, waves, current) is described by the scenario. The recognized stability failure modes and corresponding scenarios are outlined in papers [10-12]. The ship exposed to beam wind and waves, in the so called dead ship condition, is one of the scenarios, presently addressed by the Weather Criterion. Exposure time would then represent the duration of the scenario.

Sufficient stability from the probabilistic point of view is attained if the probability of the stability failure $P_{s f}$ does not exceed an acceptable level $P_{a}$ :

$$
P_{s f}<P_{a}
$$

The probability may be assessed using the following formula (see e.g. [10]):

$$
P_{s f}=1-\exp \left\{-N_{c} \exp \left[-\frac{1}{2}\left(\frac{\phi-\bar{\varphi}}{s_{\varphi}}\right)^{2}\right]\right\}
$$


It is therefore necessary to know the statistical properties of the roll motion (mean roll angle and standard deviation), which, under the assumption of ergodicity, could be derived from a sufficiently long rolling record.

Time history of roll is obtained from a mathematical model of ship motions. In this case, a simple, single degree-of-freedom model was used: a nonlinear differential equation of roll of a ship exposed to the gusting beam wind and irregular beam waves:

$$
\begin{aligned}
\left(J_{x}+m_{\varphi}\right) \cdot \ddot{\varphi}+M_{\text {damp }}(\dot{\varphi}) & +M_{s t}(\varphi)= \\
= & M_{\text {wave }}(t)+M_{\text {wind }}(t)
\end{aligned}
$$

Mathematical model (2) was thoroughly described in paper [6]. However, some of its features should be outlined here as well.

Model (2) introduces a stochastic treatment of exciting moments due to irregular waves and gusting wind:

$$
\begin{gathered}
M_{\text {wave }}=\left(J_{x}+m_{\varphi}\right) \frac{\omega_{\varphi}^{2}}{g} \sum_{n=1}^{N} A_{n} \omega_{n}^{2} \cos \left(\omega_{n} t-\varepsilon_{n}\right) \\
M_{\text {wind }}=\frac{1}{2} \rho A_{w} c l_{w} \cdot\left[\bar{v}+\sum_{n=1}^{N} B_{n} \cos \left(\omega_{n} t+\beta_{n}\right)\right]^{2}
\end{gathered}
$$

where wave and wind gust amplitudes are acquired from the appropriate wave and wind spectra:

$$
\begin{aligned}
& A_{n}=\sqrt{2 S_{\text {wave }}\left(\omega_{n}\right) \cdot d \omega}, \\
& B_{n}=\sqrt{2 S_{\text {wind }}\left(\omega_{n}\right) \cdot d \omega},
\end{aligned}
$$

and $\varepsilon_{n}$ and $\beta_{n}$ represent random phases of wave and wind gust components.

On the left-hand side of (2), the damping moment, represented by the quadratic term, is assessed by the simplified, Weather Criterion-based approach:

$$
M_{\text {damp }}=\mu \cdot \dot{\varphi}|\dot{\varphi}| \approx \frac{0.5 \cdot\left(J_{x}+m_{\varphi}\right)}{\left(k \cdot X_{1} X_{2}\right)^{2}} \cdot \dot{\varphi}|\dot{\varphi}| .
$$

The righting moment is:

$$
M_{s t}=g \Delta \cdot h(\varphi)=g \Delta \cdot\left[G M \sin \varphi+h^{\prime}(\varphi)\right],
$$

where $h^{\prime}(\varphi)$ represents the residuary righting arm, approximated by a high-order odd polynomial:

$$
h^{\prime}(\varphi) \approx \sum_{n=0}^{N} a_{2 n+1} \varphi^{2 n+1}
$$

Finally, added mass $m_{\varphi}$ of roll is assumed to be frequency-independent and equal to $0.1 J_{x}$. The equation (2) is solved numerically, using Runge-Kutta method. It should be noted that, although (2) in many aspects represents a simplified model of ship motion in beam storm, it still describes the stability of the ship exposed to wind and waves in a much more accurate manner than the classical, deterministic approach used in the Weather Criterion.

\section{THE SAMPLE SHIP}

The investigation was carried out using a typical small container vessel (whose main particulars are given in Table 1) as the sample ship. The body plan of the sample ship is given in Fig. 1. Such vessels are normally employed in the short sea shipping and make numerous port calls. Given that many port tariffs are based on the gross tonnage, a need for a decrease of operational costs generally results in low freeboards, as it was pointed out in the study [13]. On the other hand, large lateral area makes this type of ships vulnerable to gusting beam wind.

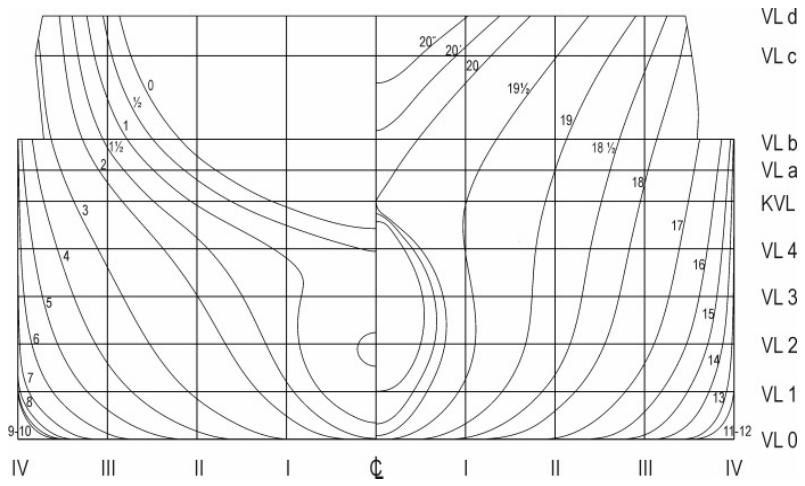

Figure 1. Body plan of the sample ship

Table 1. Main particulars of the sample vessel

\begin{tabular}{|llc|}
\hline $\mathrm{L}_{\mathrm{pp}}$ & {$[\mathrm{m}]$} & 120 \\
\hline $\mathrm{B}$ & {$[\mathrm{m}]$} & 21.3 \\
\hline $\mathrm{d}$ & {$[\mathrm{m}]$} & 7.14 \\
\hline$\Delta$ & {$[\mathrm{t}]$} & 14314 \\
\hline \multirow{2}{*}{ TEU } & {$[-]$} & 753 (four tiers) \\
& & 822 (five tiers) \\
\hline \multirow{2}{*}{$\mathrm{A}_{\mathrm{w}}$} & \multirow{2}{*}[\mathrm{m}^{2}]{} & 1735 (four tiers) \\
\end{tabular}

Two different loading configurations were examined, with four and five container tiers on the deck (denoted as SR4 and SR5 respectively). In addition, it was supposed that the ship may or may not have the bilge keels, whereby "-bk" notation in the test case name indicates the ship with bilge keels.

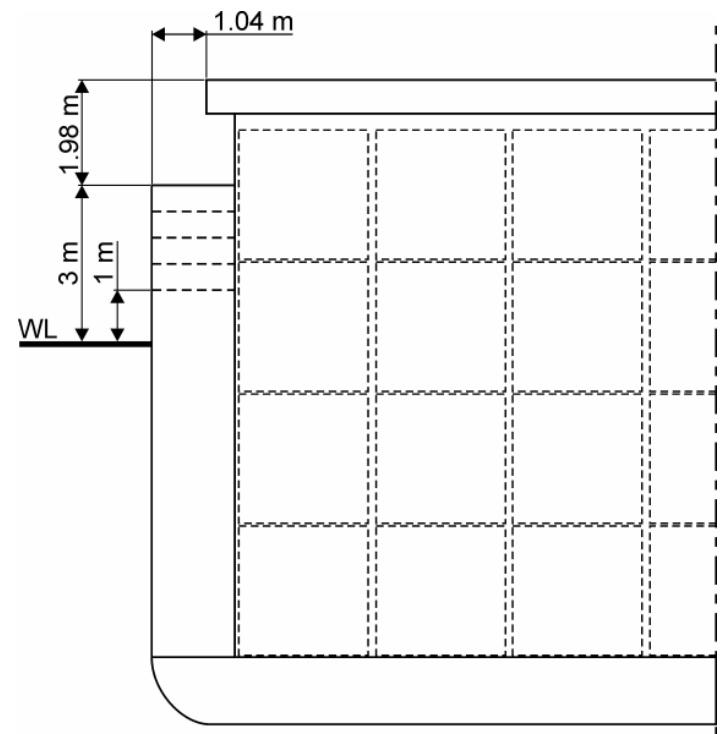

Figure 2. Freeboard height variation 
The minimal $F_{B}$ of the sample ship, determined following the ICLL provisions and taking into account specific design features, would be $1.236 \mathrm{~m}$. The freeboard was therefore varied in the range $1 \mathrm{~m} \div 3 \mathrm{~m}$, with a $0.5 \mathrm{~m}$ step, whereby, for the sake of simplicity, it was assumed that the ship displacement and the volume of the cargo space remain the same. The freeboard variation is shown in Fig. 2.

\section{NUMERICAL EXPERIMENTS}

The experiments were carried out using the Bretschneider's wave spectrum defined by the $H_{s}=11 \mathrm{~m}$ and a modal period equal to the natural period of roll, $T_{m}=T_{\varphi}$. Mean wind speed is $26 \mathrm{~m} / \mathrm{s}$. The wind gust amplitudes are derived from the Davenport spectrum. Environmental conditions, thus, correspond to the Weather Criterion storm, but wind and waves are regarded as stochastic processes. It is assumed that the exposure time is two hours. Each record used in the probability assessment is $1200 \mathrm{~s}$ long, excluding the first $28 \mathrm{~s}$ in order to rule out the influence of transient effects. Finally, the acceptable level of probability failure is adopted to be $P_{a}=\boldsymbol{O}\left(10^{-3}\right)$, as defined in [6].

The probability of a stability failure in two hours as a function of metacentric height is presented in Fig. $3 \div$ 6 . Each curve corresponds to a certain freeboard height. The influence of freeboard on dynamic stability strongly depends on the metacentric height. Obviously, stability lever at smaller $G M$ values is dominated by the residuary, "form" stability, whereas at higher metacentric heights relative difference between stability levers decreases. The analysis of stability in wind and waves, however, offers an additional insight, beyond the classic ship stability knowledge.

All the curves have the characteristic "saddle" form, indicating that except a minimal, there is also a maximal $G M$, for which the acceptable probability of stability failure is attained. It follows that a range of safe metacentric heights can be established; any $G M$ value outside the safe range would result in $P_{s f}>P_{a}$.

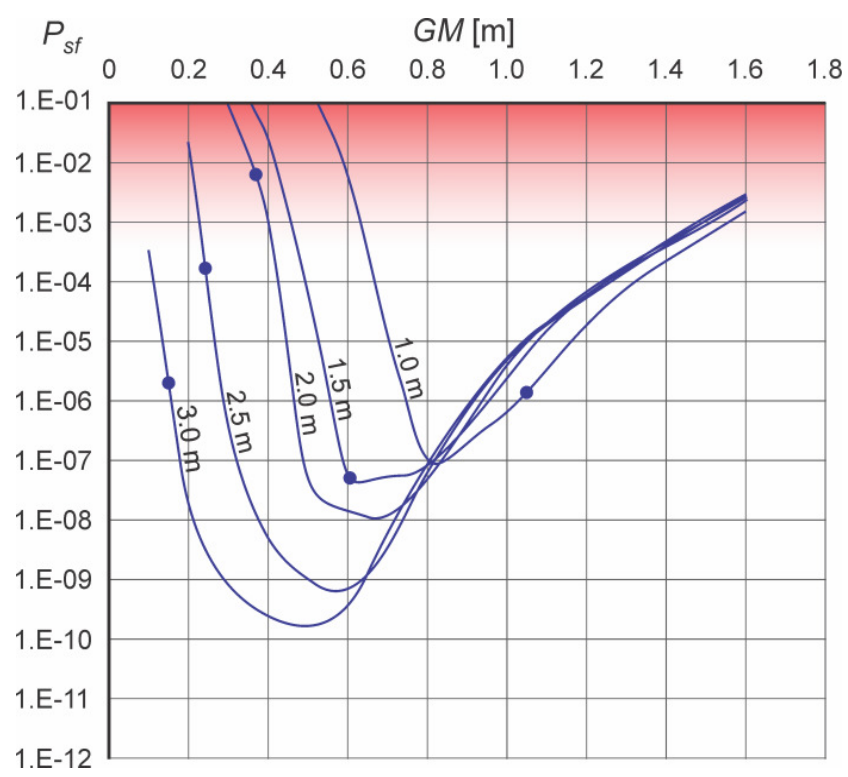

Figure 3. Probability of stability failure of the sample ship with five container tiers and bilge keels

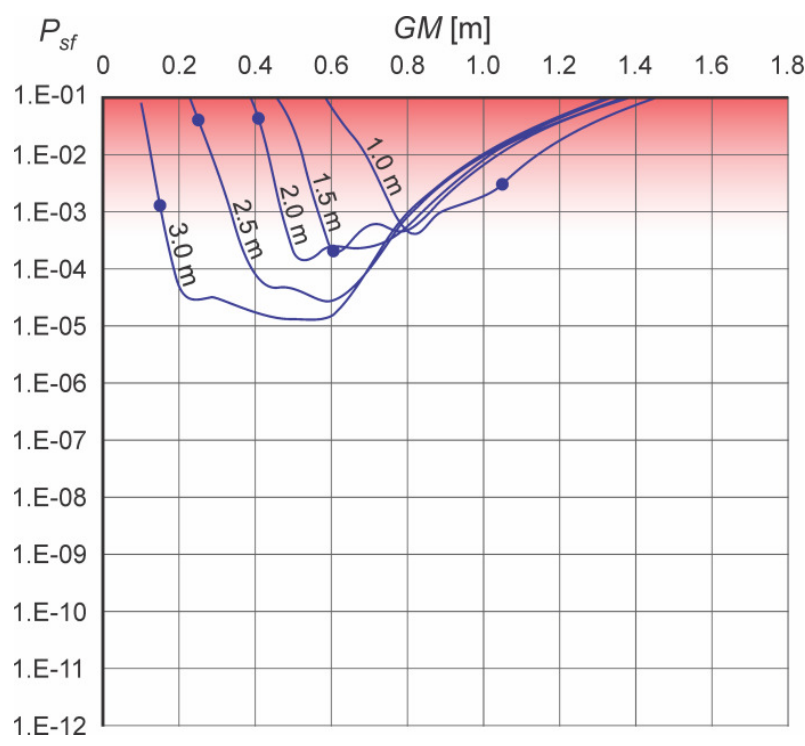

Figure 4. Probability of stability failure of the sample ship with five container tiers, without bilge keels

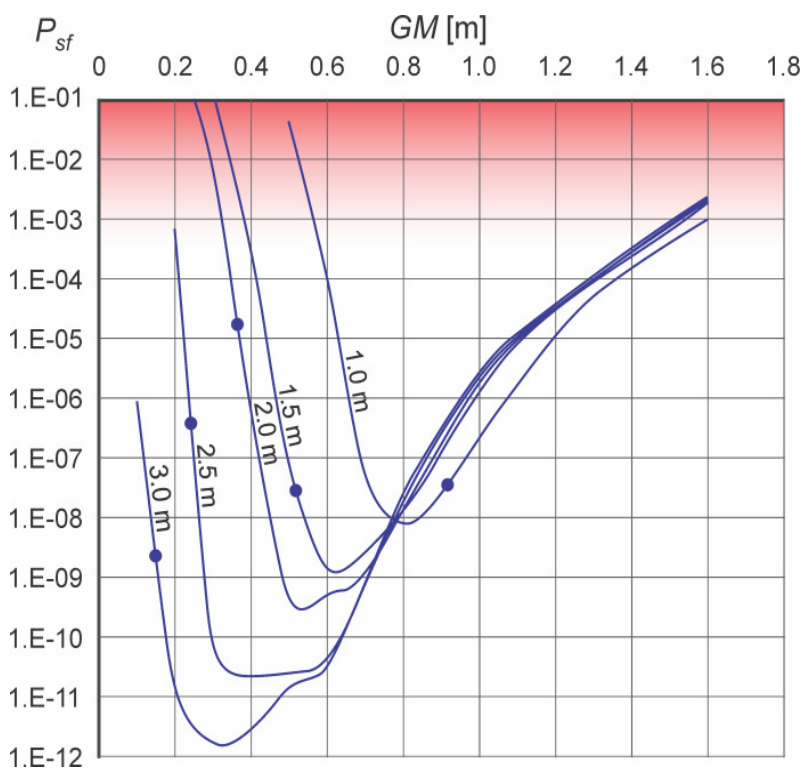

Figure 5. Probability of stability failure of the sample ship with four container tiers and bilge keels

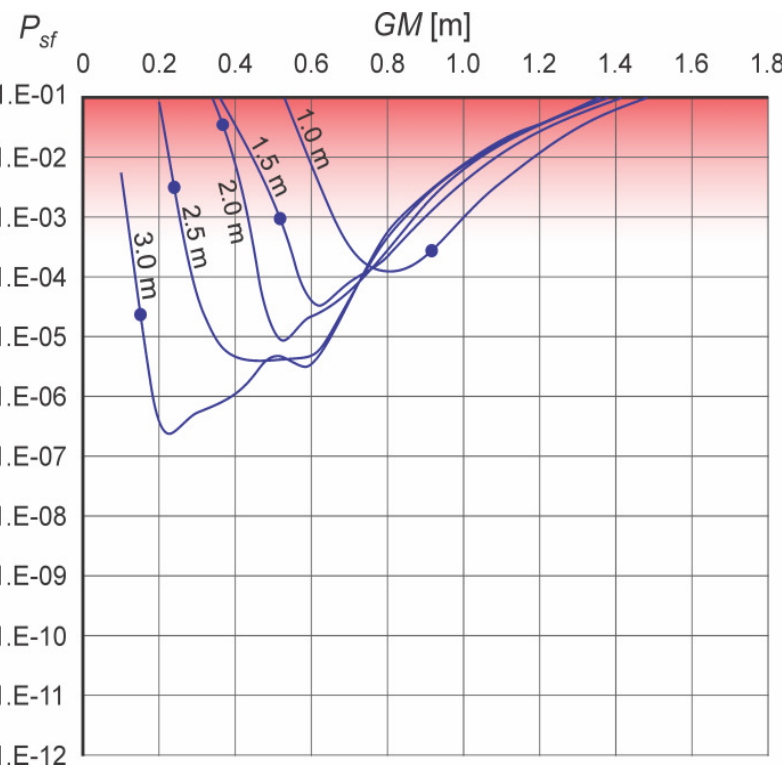

Figure 6. Probability of stability failure of the sample ship with four container tiers, without bilge keels 
Furthermore, an "optimal" metacentric height could be found, corresponding to the least $P_{s f}$ within the examined span of metacentric heights. In paper [5] such "saddle" curves were obtained for a feeder, a car carrier and a passenger ship. The similar results were also reported in papers [14] and [15]. This interesting outcome of the probabilistic analysis is in contrast to the classical ship stability concept according to which the increase of metacentric height could only be beneficial for the stability of the vessel.

The increase of freeboard is followed by the widening of the range of the metacentric heights that ensure sufficient stability from the probabilistic point of view. Additional $2 \mathrm{~m}$ of freeboard yield the increase of the safe range of metacentric heights by more than $40 \%$ for ships with bilge keels. The upper boundary of this zone, however, remains practically the same; the range expands towards the lower metacentric heights. Furthermore, the optimal metacentric height decreases as well.

The results also indicate that the influence of wind increases as the metacentric heights decreases. For instance, the $P_{s f}$ values for four and five container tiers differ up to three orders of magnitude for $G M=0.4 \mathrm{~m}$ (see Fig. 3 and 5). On the other hand, for metacentric heights higher than $G M \approx 0.9 \mathrm{~m}$ the probability is not influenced by increased wind loads. This result is completely in line with the discussion by Hofman given in [16].

Table 2. Minimal metacentric heights of examined vessels according to the IS Code 2008

\begin{tabular}{|l|c|c|c|c|}
\hline Test case & SR4-bk & SR4 & SR5-bk & SR5 \\
\hline$F_{B}[\mathrm{~m}]$ & \multicolumn{4}{|c|}{$G M_{\min }[\mathrm{m}]$} \\
\hline 1 & 0.917 & 0.917 & 1.048 & 1.048 \\
\hline 1.5 & 0.52 & 0.52 & 0.607 & 0.607 \\
\hline 2 & 0.367 & 0.367 & 0.369 & 0.411 \\
\hline 2.5 & 0.242 & 0.242 & 0.242 & 0.251 \\
\hline 3 & 0.15 & 0.15 & 0.15 & 0.15 \\
\hline
\end{tabular}

Minimal metacentric heights calculated according to the present ship stability regulations [17] for each of the arrangements examined are given in Table 2 and denoted with dots on $P_{s f}$ lines in Fig. $3 \div 6$. The safety levels attained with $G M_{\text {min }}$ differ up to five orders of magnitude. There is also a number of cases where minimal stability requirements of IS Code do not provide sufficient safety from the probabilistic point of view. Furthermore, it seems that the rules, by prescribing the same values of $G M_{\min }$, fail to recognize the influence of wind in the range of smaller metacentric heights. For instance, the minimal metacentric heights as required by the deterministic rules are the same for both the SR4-bk and SR5-bk test cases with $2 \mathrm{~m}$ freeboard. The probabilistic analysis, however, shows that the $P_{s f}$ in these cases differs by three orders of magnitude. The similar conclusions apply to $F_{B}=2.5 \mathrm{~m}$ and $F_{B}=3 \mathrm{~m}$. It is also noteworthy that, in most of the cases examined, the $G M_{\min }$ values of the ships with the same lateral area are equal regardless of whether the vessel has bilge keels or not. Interestingly, in such cases, the limitation of the static angle of heel to $80 \%$ of the angle at which deck enters the water, due to the constant wind lever $l_{w l}$, proved to be the most stringent requirement of the rules [17]. As a consequence, the minimal metacentric height of the low freeboard vessels (e.g. $F_{B}=1 \mathrm{~m}$ ) is "pushed" towards the higher $G M$ values which seems to be reasonable from the static stability point of view. However, the applied analysis of stability in waves reveals that, in storms, the ship would be safer at $G M \approx 0.8 \mathrm{~m}$ than at $G M_{\min } \approx 1.05 \mathrm{~m}$ prescribed for the five container tiers arrangement and that her safety may even be compromised as in the test case SR5 (Fig. 5). Further increase of metacentric height above the prescribed values would only be detrimental for stability in seaway, in each of the investigated cases.

Unlike the case of low metacentric heights, the probability of stability failure is practically not affected by the freeboard if the $G M$ is sufficiently high. This is valid for each of the configurations examined. As it was already pointed out, the stability of the sample ship in range of high metacentric heights is dominated by the roll amplitudes in waves. The safety could be improved by the roll stabilization (increase of roll damping) as demonstrated by the numerical tests for the ship fitted with bilge keels (Fig. 4 and 6). The numerical experiments indicate that the bilge keels have a considerable effect on the ship safety, decreasing the $P_{s f}$ values up to five orders of magnitude. Nevertheless, since the contribution of the bilge keels to the roll damping was modelled in a simplified manner, their influence should be regarded as qualitatively rather than quantitatively correct.

\section{CONCLUSIONS}

The paper investigates an alternative approach to freeboard assignment and attempts to quantify the influence of freeboard on dynamic stability of ships in storms using an advanced approach: a probabilistic analysis of nonlinear rolling in stochastic wind and irregular waves. The analysis was performed on a typical small multipurpose cargo ship. Contemporary design of this ship type often implies a tendency towards low freeboards, aiming at the decrease of gross tonnage and, consequently, the operational and other costs. This, in turn, results in reduced stability margin, as emphasized in papers [2] and [3].

The analysis showed that the increase of freeboard proves to be beneficial for the safety in rough weather for ships operating at lower metacentric heights. Indeed, the metacentric heights of the examined vessel, when fully laden, with five container tiers on the deck, may vary in range $0.15 \mathrm{~m} \div 0.8 \mathrm{~m}$, depending on the vertical cargo weight distribution. This means that, for instance, at $G M=0.4 \mathrm{~m}$, the $P_{s f}$ of the ship with five container tiers on the deck and bilge keels, would be $\boldsymbol{O}\left(10^{-3}\right)$ in case that $F_{B}=2 \mathrm{~m}$. The increase of freeboard by $0.5 \mathrm{~m}$, however, would decrease the probability of stability failure by five orders of magnitude and expand the range of the safe metacentric heights by $0.2 \mathrm{~m}$ (Fig. 3).

The probabilistic analysis confirmed that the minimal freeboard, as prescribed by the ICLL, considerably reduces the safety margin. In case that $F_{B}$ $=1.5 \mathrm{~m}$, which would be just above the $F_{B \min }$ according 
to ICLL, the metacentric height of the ship with five container tiers and bilge keels should be greater than $0.45 \mathrm{~m}$ in order to attain the required level of safety (Fig. 3). The safe range of attainable $G M$ values thus reduces to $0.3 \mathrm{~m}$ and the ship stability in storms becomes more sensitive, for instance, to loading errors, which are found to be one of the main risk-contributing factors in the operation of small container ships, as pointed out in study [3].

It was also found that the increase of freeboard height allows for an additional container tier. For instance, with $F_{B}=1.5 \mathrm{~m}$ and four container tiers, the ship could be considered as safe if her metacentric heights are in range $0.4 \mathrm{~m} \div 1.5 \mathrm{~m}$ (Fig. 5). The same span of safe metacentric heights can be achieved with five container tiers as well, if the $F_{B}$ is increased to $2 \mathrm{~m}$ (Fig. 3).

In the examined case, the economic effects of the gross tonnage change due to the freeboard variation may not be so obvious. Since the gross tonnage of the analyzed vessel is around 7000 GT, the GT-based thresholds used in international regulations related to crew and equipment requirements are either considerably lower (300 GT, 500 GT, 1500 GT, 3000 GT) or much higher (10000 GT) and therefore do not affect related costs. Nevertheless, additional $2 \mathrm{~m}$ of freeboard increase the gross tonnage roughly by $4 \%$ which could generate considerable extra operational costs. Furthermore, in order to gain a better insight into the economic consequences it would be necessary to take into account the change of the steel weight and the associated production costs in relation to the adopted freeboard height. Presently, for the sake of simplicity, these effects were disregarded.

The question of effectiveness of freeboard on ship safety in rough weather, however, remains open. It should be noted that a number of influences was deliberately omitted. As it was pointed out in [12] and in more details in [18], the description of the physical phenomena related to deck immersion would require inclusion of additional terms in the mathematical model. Moreover, the ability of a single degree-of-freedom model to appropriately describe the roll motion in seaway may be questioned as well, as pointed out in [10]. These and some other issues will be the subject of the future research.

\section{ACKNOWLEDGMENT}

The research presented in the paper was performed within the framework of the project "Development of Next Generation of Safe, Efficient, Ecological (SEECO) Ships" executed by Department of Naval Architecture, Faculty of Mechanical Engineering University of Belgrade. The project is partly financed by Serbian Ministry of Education, Science and Technology Development, Contract No. TR35009. The results of the research are in more detail given in the MSc thesis "A Probabilistic Analysis of Influence of Freeboard on the Stability of a Small Multipurpose Cargo Ship" [19] defended at the University of Belgrade, Faculty of Mechanical Engineering, Department of Naval Architecture.

\section{REFERENCES}

[1] Schneekluth, H., Bertram, V.: Ship Design for Efficiency and Economy, Butterworth Heineman, Oxford, 1998.

[2] Boonstra, H., de Jongh, M.P., Pallazi, L.: Safety Assessment of Small Container Feeders, in: Proceedings of the $9^{\text {th }}$ Symposium on Practical Design of Ships and Other Floating Structures, 1217.09.2004, Luebeck-Travemuende, paper 15 .

[3] ter Bekke, E.C.A., Willeboordse, E.J., van Daalen, E.F.G., Boonstra, H., Kiezer, E.F.G., Ale, B.: Integrated safety assessment of small container ships, in: Proceedings of the $8^{\text {th }}$ International Conference on Probabilistic Safety Assessment and Management, 14-18.05.2006, New Orleans .

[4] Bulian, G., Francescutto, A.: A simplified modular approach for the prediction of the roll motion due to the combined action of wind and waves, Proceedings of Institution of Mechanical Engineers, Part M, Journal of Engineering for the Maritime Environment, 218 (3), pp. 189-212, 2004.

[5] Vassalos, D., Jasionowski, A., Cichowicz, J.: Issues related to the weather criterion, International Shipbuilding Progress, 51 (2/3), pp. 251-271, 2004.

[6] Hofman, M., Bačkalov, I.: Weather Criterion for Seagoing and Inland Vessels - Some New Proposals, in: Proceedings of International Conference on Marine Research and Transportation, 19-21.09.2005, Ischia, pp. 53-62.

[7] Bačkalov, I., Kalajdžić, M., Hofman, M.: Inland Vessel Rolling due to Severe Beam Wind: a Step towards a Realistic Model, Probabilistic Engineering Mechanics, Vol. 25, No. 1, January 2010, pp 18-25.

[8] Hofman, M., Bačkalov, I.: Risk-Based Analysis of Inland Vessel Stability, in: Proceedings of the $11^{\text {th }}$ International Ship Stability Workshop, 2123.06.2010, Wageningen, pp. 67-72.

[9] Bačkalov, I.: Impact of contemporary ship stability regulations on safety of shallow-draught inland container vessels, Safety Science, Vol. 72, February 2015, pp 105-115.

[10]Bulian, G., Francescutto, A.: Second Generation Intact Stability Criteria: on the validation of codes for direct stability assessment in the framework of an example application, Polish Maritime Research, No. 4(80), Vol. 20, pp. 52-61, 2013.

[11] Peters, W., et al.: The Second Generation Intact Stability Criteria: An Overview of Development, SNAME Transactions, Vol. 119, 2011.

[12]Belenky, V., de Kat, J.O., Umeda, N.: Toward Performance-Based Criteria for Intact Stability, Marine Technology, Vol. 45, No. 2, pp. 101-123, April 2008.

[13] Policy Research Corporation, Consequences of the Gross Tonnage Measurement, Antwerp/Rotterdam, 2005.

[14] Umeda, N., Maki, A., Izawa, S., Sano, H., Sogawa, Y., Maeda, E., Tsukamoto, I.: New Generation 
Intact Stability Criteria: a Step Forward, in: Proceedings of the $10^{\text {th }}$ International Conference on Stability of Ships and Ocean Vehicles, 2226.06.2009, St. Petersburg, pp. 129-140.

[15]Bulian, G., Francescutto, A.: Considerations on Parametric Roll and Dead Ship Conditions for the Development of Second Generation Intact Stability Criteria, in: Proceedings of the $12^{\text {th }}$ International Ship Stability Workshop, 12-15.06.2011, Washington, D.C., pp. 7-18.

[16] Vantorre, M., Hofman, M., Bačkalov, I.: Probabilistic Safety of Estuary Vessels Based on Nonlinear Rolling in Wind and Waves, The Transactions of RINA - International Journal of Maritime Engineering, Vol. 152, Part A3, pp. 159161, 2010.

[17] Resolution MSC.267(85) "Adoption of the International Code on Intact Stability, 2008 (2008 IS CODE)", Maritime Safety Committee, London, 4 December 2008.

[18] Belenky, V.L., Sevastianov, N.B., Stability and Safety of Ships. Volume 2: Risk of Capsizing, The Society of Naval Architects and Marine Engineers, New Jersey, 2007.

[19] Rudaković, S.: A Probabilistic Analysis of Influence of Freeboard on the Stability of a Small Multipurpose Cargo Ship (In Serbian), MSc thesis, Faculty of Mechanical Engineering, University of Belgrade, Belgrade, 2014.

\section{NOMENCLATURE}

$A_{n} \quad$ amplitude of $n$-th wave component

$A_{w} \quad$ lateral ship area exposed to wind

$B$ breadth

$B_{n} \quad$ wind gust amplitudes of $n$-th wind

c drag coefficient

d draft

$F_{B} \quad$ freeboard height

$g$ gravitational acceleration

GM metacentric height

$h \quad$ total stability lever

$H_{s} \quad$ mean wave height

$h^{\prime} \quad$ residuary stability lever

$J_{x} \quad$ moment of inertia longitudinal central axes

$k \quad$ bilge keel factor

$L_{p p} \quad$ length between perpendiculars

$l_{w} \quad$ wind moment lever

$M_{\text {dam }}$ damping moment

$M_{s t} \quad$ stability moment

$M_{\text {wave }}$ wave moment

$M_{\text {wind }}$ wind moment

$m_{\varphi} \quad$ additional mass of roll
$N_{c} \quad$ numbers of zero crossings

$P_{a} \quad$ acceptable level of probability

$P_{s f} \quad$ probability of stability failure

$S_{\text {wave }} \quad$ wave spectrum

$S_{\text {wind }} \quad$ wind spectrum

$s_{\varphi} \quad$ standard deviation

$t$ time

$T_{m} \quad$ modal period of ship

$T_{\varphi} \quad$ natural roll period of ship

$\bar{v} \quad$ mean wind speed

$X_{1} \quad$ beam to draft ratio factor

$X_{2} \quad$ block coefficient factor

$\beta_{n} \quad$ random phase of $n$-th wind component

$\Delta \quad$ displacement

$\varepsilon_{n} \quad$ random phase of $n$-th wave component

$\rho \quad$ air density

$\varphi \quad$ roll angle

$\phi \quad$ maximum roll angle

$\bar{\varphi} \quad$ mean value of roll angle

$\dot{\varphi} \quad$ angular speed of roll

$\ddot{\varphi} \quad$ angular acceleration of roll

$\omega_{n} \quad$ frequency of $n$-th wave component

$\omega_{\varphi} \quad$ natural roll frequency of ship

GT gross tonnage

TEU twenty-foot equivalent unit

\section{ПРОБАБИЛИСТИЧКА АНАЛИЗА УТИЦАЈА СЛОБОДНОГ БОКА НА СТАБИЛИТЕТ БРОДА У ОЛУЈИ}

\section{И. Бачкалов, С. Рудаковић}

Слободни бок морских бродова одређује се помоћу детерминистичких одредби Међународне конвенције о теретној водној линији. У овом раду, међутим, користи се пробабилистички поступак како би се оценио утицај слободног бока на динамичку стабилност брода у олуји. Серијом нумеричких експеримената, процењује се вероватноћа губитка стабилитета малог вишенаменског теретног брода изложеног истовременом дејству нерегуларних бочних таласа и удара стохастички променљивог бочног ветра, при чему је висина слободног бока систематски варирана. Утицај слободног бока квантификован је опсегом метацентарских висина при којима се брод може сматрати стабилним са пробабилистичке тачке гледишта. Рад представља корак ка успостављању процедуре чијом би се употребом у поступку пројектовања могла постићи боља равнотежа између сигурности и економичности брода. 